\title{
DAMPAK PRAKTIK RENTENIR TERHADAP KESEJAHTERAAN PEDAGANG ECERAN DALAM PERSPEKTIF EKONOMI ISLAM
}

\author{
Utia Khasanah $^{1}$, Muh. Wahyuddin Abdullah ${ }^{2}$, Amiruddin K. ${ }^{3}$ \\ ${ }^{1}$ UIN Alauddin Makassar || uthykhazanah@gmail.com \\ ${ }^{2}$ UIN Alauddin Makassar || tosir_wahyu@yahoo.com \\ ${ }^{3}$ UIN Alauddin Makassar
}

\begin{abstract}
Abstrak
Kebutuhan hidup manusia semakin meningkat seiring dengan semakin modernnya jaman. Hal tersebut menjadi permasalahan bagi sebagian masyarakat nelayan dengan penghasilan yang tak menentu. Sehingga keluarlah ide menjalankan usaha lain sebagai pedagang eceran. Namun terkendala tidak adanya modal yang kemudian menjadi peluang bagi rentenir untuk menjalankan bisnisnya. Penelitian ini bertujuan untuk mengetahui dampak praktik rentenir terhadap kesejahteraan pedagang eceran ditinjau menurut prinsip ekonomi Islam. Penelitian ini menggunakan metode kualitatif deskriptif dengan pendekatan paradigma kritis. Sumber data penelitian ialah hasil wawancara terhadap rentenir dan pedagang eceran, serta data tertulis dari kantor Kelurahan Barrang Caddi Kecamatan Sangkarrang Kota Makassar dan studi kepustakaan yang relevan. Pengujian keabsahan data menggunakan uji kredibilitas data. Hasil penelitian ini menunjukkan bahwa praktik rentenir telah ada sejak tahun 2013 dikarenakan kebutuhan modal dan tidak adanya lembaga keuangan formal dengan proses utang piutang yang mudah dan pembayarannya menggunakan sistem cicil per hari. Praktik rentenir tidak mampu mensejahterakan pedagang eceran, hal ini dikarenakan pinjaman modal dari rentenir hanya mampu membantu pedagang eceran dalam memenuhi kebutuhan materialnya, namun tidak pada kebutuhan spiritual. Selain itu praktik riba yang dilakukan rentenir tidak sesuai dengan prinsip ekonomi Islam yaitu prinsip keadilan, prinsip ta'awun dan prinsip maslahat.
\end{abstract}

Kata Kunci: Praktik Rentenir, Kesejahteraan, Pedagang Eceran, Prinsip Ekonomi Islam 


\begin{abstract}
Human life needs are increasing along with the increasingly modern era. This is a problem for some fishing communities with uncertain income. So the idea is to run another business as a retail trader. But it is constrained by the lack of capital which then becomes an opportunity for loan sharks to run their businesses. This study aims to determine the impact of moneylender practices on the welfare of retail traders according to Islamic economic principles. This study uses a qualitative descriptive method with a critical paradigm approach. The source of research data is the result of interviews with loan sharks and retailers, as well as written data from Barrang Cad Urban Village office in Sangkarrang District, Makassar City and relevant literature studies. Testing the validity of the data using the data credibility test. The results of this study indicate that moneylender practices have existed since 2013 due to capital requirements and the absence of formal financial institutions with easy debt processing and payments using installments per day. The practice of loan sharks is not capable of prospering retail traders, this is because capital loans from moneylenders are only able to help retail traders in fulfilling their material needs, but not on spiritual needs. In addition, the practice of usury by moneylenders is not in accordance with Islamic economic principles, namely the principle of justice, ta'awun principle and the principle of maslahat.
\end{abstract}

Keywords: Practice of Moneylenders, Welfare, Retailers, Principles of Islamic Economics

PENDAHULUAN

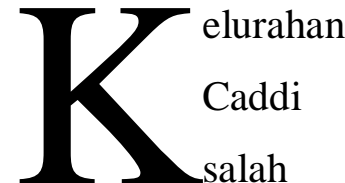

Nelayan merupakan profesi yang

Barang bergantung pada potensi kekayaan merupakan sumber daya laut yang kemudian hasil satu pulau ikan tangkapan melaut di jual untuk dalam gugusan pulau atau kepulauan memenuhi kebutuhan hidup sehari-hari supermode, Sulawesi Selatan. Secara seperti kebutuhan pangan, sandang, administratif termasuk ke dalam papan, pendidikan, kesehatan dan lainwilayah kota Makassar, Kecamatan lain. Namun profesi nelayan pun tak Kepulauan Sangkarrang. Mata lepas dari pengaruh cuaca yang pencaharian masyarakat kelurahan terkadang memaksa mereka untuk tidak Barrang Caddi cenderung beragam. bekerja. Sehingga penghasilan nelayan Namun sekitar $75 \%$ penduduk pun tak menentu. menggantungkan diri dari aktivitas Arus modernisasi yang datang nelayan (PIU, 2015: 12).

dengan berbagai macam corak pemikirannya telah memberikan 
sumbangsih besar terhadap kemajuan dan kemudahan bagi kehidupan masyarakat. Semakin majunya jaman memberikan dampak pada meningkatnya kebutuhan masayarakat. Masyarakat dituntut agar mengikuti segala hal dan kemudahan dalam arus modernitas (Sukidin, 2009: 217). Hal tersebutlah yang mendorong masyarakat untuk melakukan usaha lain sebagai upaya meningkatkan penghasilan keluarga. Terkadang masyarakat memiliki dua profesi dalam rumah tangga, dimana istri turut membantu suami dalam mencari nafkah atau pun suami beralih profesi untuk memperoleh penghasilan yang lebih layak. Di Kelurahan Barrang Caddi Kecamatan Kepulauan Sangkarrang Kota Makassar pun akan mudah dijumpai hal yang demikian yaitu kepala rumah tangga berprofesi menjadi nelayan, kemudian istrinya menjadi pedagang eceran dan berjualan di depan rumah. Selain itu, tak sedkit dari suami yang sebelumnya berprofesi sebagai nelayan beralih profesi menjadi pedagang eceran.

Permasalahan permodalan senantiasa dihadapi ketika hendak menjalankan sebuah usaha (Tira, 2016:
34). Hal tersebut pun dialami oleh masyarakat di Kelurahan Barrang Caddi Kecamatan Kepulauan Sangkarrang Kota Makassar. Faktor utama sulitnya akses permodalan dikarenakan belum berdirinya lembaga fasilitas perekonomian di tengah kehidupan masyarakat. Adanya permintaan modal maupun dana tunai memberikan peluang tumbuhnya praktik rentenir.

Praktik rentenir di kelurahan Barrang Caddi Kecamatan Kepulauan Sangkarang Kota Makassar sangat mudah ditemukan. Masyarakat yang memiliki kelebihan modal menjadikannya sebagai peluang usaha yang menguntungkan. Selain itu dalam praktik rentenir proses peminjaman pun sangat mudah tanpa melalui prosedur administrasi yang panjang seperti pada lembaga keuangan formal. Sehingga hal tersebutlah yang menjadi daya tarik bagi masyarakat untuk menggunakan jasa rentenir.

Pedagang eceran berharap dengan adanya dana dari rentenir tersebut akan membantu mereka dalam hal pemenuhan kebutuhan maupun permodalan. Sehingga akan mampu meningkatkan taraf hidup pedagang 
ecer, namun faktanya dampak positif rentenir hanya bersifat sementara. Hal itu disebabkan karena pedagang eceran mempunyai beban tambahan, selain harus memenuhi kebutuhan hidupnya sehari-hari, pedagang eceran pun harus menyisihkan penghasilannya untuk membayar cicilan kredit dari rentenir, sedangkan dalam menjalankan usahanya keuntungan yang didapatkan tidak menentu bahkan kadang merugi. Namun, pihak rentenir tidak memperdulikan hal tersebut. Nasabah tetap mempunyai kewajiban untuk membayar pinjamannya.

Berdasarkan uraian di atas, maka penulis tertarik untuk mengetahui secara rinci bagaimana Dampak Praktik Rentenir terhadap Pedagang Eceran dalam Perspektif Ekonomi Islam. Oleh karena itu, penulis mengambil judul "Dampak Praktik Rentenir terhadap Kesejahteraan Pedagang Eceran dalam Perspektif Ekonomi Islam di Barrang Caddi Kota Makassar."

\section{PEMBAHASAN}

\section{Prinsip-Prinsip Ekonomi Islam}

Terdapat beberapa pendapat mengenai prinsip-prinsip yang menjadi landasan dalam Ekonomi Islam. Nilainilai universal ekonomi Islam dan sekaligus sebagai landasan filosofis untuk pengernbangan ekonomi Islam yaitu al-tauhid (keesaan dan keagungan Tuhan), al-rububiyah (pengaturan Tuhan akan sumber alam), al-khilafaft (pemerintahan), dan al-tazkiyah (kebersihan), kesucian dan (pengembangan). Nilai-nilai universal tersebut selanjutnya dapat diklafikasikan menjadi enam macam, yaitu al-tauhid (dalam arti al-uluhiyah dan rububiyah), al-'adl (keadilan), alnubuwwah (kenabian), al-khilafah (pemerintahan), al-tazkiyah (kebersihan atau kesucian) dan al-ma'ad (kembali, hasil, hari kemudian). Keenam nilai universal ini yang mewarnai dan menjadi titik tolak segala norma, aturan, kebijakan, dan penyelesaian persoalan ekonomi Islam (Illi dan Rafidah, 2009: 17). Sedangkan, Mursal (2015: 75) berpendapat bahwa prinsipprinsip ekonomi Islam yaitu prinsip tauhid, prinsip keadilan, prinsip maslahat, prinsip ta'awun, dan prinsip keseimbangan.

\section{Prinsip Keadilan}

Dalam terminologi fikih, adil adalah menempatkan sesuatu pada tempatnya dan memberikan sesuatu hanya pada yang berhak serta memperlakukan sesuatu pada posisinya 
(Mursal, 2015: 78). Dalam terminologi Islam, keadilan adalah antiteis dari kezaliman dan kesewenang-wenangan. Namun ia juga bermakna aktif yang tercerminkan dalam "modernisasi Islam yang universal" yang bersifat moderat dan tidak berpihak atau cenderung kepada satu sisi saja, dan ia juga tidak mengisolasi dirinya dari keduanya tidak berbeda sama sekali dari keduanya. Namun ia adalah senyawa dari unsur-unsur keadilan, kebenaran, dan kebaikan yang ada pada keduanya. Kemudian dari keduanya diciptakan satu sikap adil yang berdiri ditengah dua kezaliman, dari kebenaran di antara dua kebatilan, sikap moderat di antara dua sikap ekstrem (Muhammad, 1999: 115).

Beberapa pendapat merumuskan keadilan diantaranya, Thomas Aquinas mendefiniskan keadilan sebagai kecenderungan yang tetap dan kekal untuk memberikan kepada setiap orang apa yang menjadi haknya (Bahder, 2014: 122). Sedangkan Nurdin (2011: 122) mendefiniskan keadilan sebagai tindakan atau perlakukan yang seimbang dan sesuai dengan ketentuan, tidak membenarkan yang salah dan tidak menyalahkan yang benar, walaupun menghadapi konsekuensikonsekuensi tertentu. Sedangkan secara terminologi keadilan adalah tindakan, keputusan, perlakuan, dan sebagainya.

Afifa Rangkuti (2017: 3) berpendapat bahwa pada hakikatnya keadilan adalah suatu sikap untuk memperlakukan seseorang sesuai dengan haknya. Dan yang menjadi hak setiap orang adalah diakui dan diperlakukan sesuai dengan harkat dan martabatnya, yang sama derajatnya, yang sama hak dan kewajibannya, tanpa membeda-bedakan suku, keturunan, agama, dan golongan. Keadilan merupakan suatu bentuk kondisi kebenaran ideal secara moral akan sesuatu hal, baik itu menyangkut benda ataupun orang.

\section{Prinsip Ta'awun (Tolong Menolong)}

Al-Ta'awun merupakan salah satu prinsip utama dalam interaksi muamalah. Ta'awun bermakna kerja sama, tolong menolong, saling menjamin, tidak berorientasi bisnis dan keuntungan semata (Havis, 2016: 37). Prinsip ta'awun merupakan prinsip saling membantu antar sesama dalam meningkatkan taraf hidup melalui mekanisme kerjasama ekonomi dan bisnis (Maman dan Panji, 2017: 143). Hal itu tercantum dalam QS AlMā'idah/5: 2, Allah memerintahkan bagi kita untuk Saling tolong menolong dalam hal kebajikan, dan bukan pada hal yang melanggar syari'at. Dengan tolong menolong (ta'awun) akan menumbuhkan rasa persaudaraan dan tali silaturahmi yang semakin erat, bukan hanya itu bahkan ta'awun dapat menjadi pondasi dalam membangun sistem ekonomi yang kokoh tanpa adanya kesenjangan sosial antara si kaya dan si miskin dengan cara pendistribusian harta kekayaan. Oleh karena itu ta'awun menjadi asas dalam mengimplentasikan konsep Islam tentang harta (Jirhanuddin, dkk, 2016: 132). 


\section{Prinsip Maslahat}

Kemashlahatan artinya tidak melakukan perbuatan yang mendatangkan mudharat dan tidak membuat hukuman yang menyalahi akal manusia dan itikat mereka yang bersifat individu maupun sosial kehidupan. Pandangan tersebut dilihat dari sisi ekonomi berarti bahwa melakukan aktivitas ekonomi yang melanggar nilai-nilai syar'i merupakan perbuatan merusaka bumi yang berdampak pada pribadi dan sosial yang dirasakan masa kini maupun masa yang akan datang (Hamzah, 2013: 12).

Pada hakikat kemaslahatan adalah segala bentuk kebaikan dan manfaat yang berdimensi integral duniawi dan ukhrawi, material dan spritual, serta individual dan sosial. Aktivitas ekonomi dipandang memenuhi maslahat jika memenuhi dua unsur, yakni ketaatan (halal) dan bermanfaat serta membawa kebaikan (thayyib) bagi semua aspek secara integral. Dengan demikian, aktivitas tersebut dipastikan tidak akan menimbulkan mudarat (Mursal, 2015: 80).

\section{Rentenir dalam Perspektif Ekonomi}

Dalam literatur ekonomi sekarang yang dimaksud dengan sewa ekonomi atau rente suatu faktor produksi tertentu adalah kelebihan pembayaran atas biaya minimum yang diperlukan untuk tetap mengonsumsi faktor produksi tersebut (Deliarnov, 2006: 62). Rentenir dalam KBBI didefiniskan sebagai orang yang memberi nafkah dan membungakan uang/ tukang riba/ pelepas uang atau lintah darat (Departemen Pendidikan dan Kebudayaan, 1995: 457).

Menurut Mohammad dan Sutrisni (2013: 63), rentenir disebut sebagai lintah darat karena kegiatannya menghisap habis uang masyarakat demi mendapatkan profit dengan pemberlakuan bunga pada kredit yang dijalaninya. Menurut Frans, dkk (2018: 399), pelepas uang (rentenir) adalah suatu jenis pekerjaan yang sesungguhnya tidak berbeda jauh dengan bank dan lembaga keuangan non bank yang bergerak dibidang jasa pelayanan simpan pinjam Perbedaannya, rentenir adalah wiraswasta yang tidak berbadan hukum yang mengelola usahanya sendiri dengan kebijakan dan peraturan sendiri. Rentenir biasa merupakan seseorang dalam lingkup masyarakat itu sendiri maupun pendatang di luar lingkup masyarakat yang menjadi nasabahnya. 


\section{Konsep Riba dalam Islam}

Akar kata r-b-w dalam al-Qur'an memilki makna tumbuh, menyuburkan, mengembang-kan, mengasuh, dan menjadi besar dan banyak. Akar kata ini juga digunakan dalam arti dataran tinggi. Penggunaan kata-kata tersebut tampak secara umum memiliki satu makna yaitu bertambah dalam arti kuantitas maupun kualitas (Abdullah, 2004: 27).

$$
\text { Ibnu Hajar al-Asqalani }
$$

menyatakan bahwa "intinya riba adalah kelebihan, baik dalam komoditas (itu sendiri) ataupun dalam uang, seperti dinar ditukarkan dengan tiga dinar." Menurut Allamah Mahmud al-Haan Taunki, riba berarti kelebihan atau kenaikan; dan di dalam kontrak barter (pertukaran barang dengan barang), kelebihan suatu barang yang diminta untuk ditukar dengan barang yang sama persis sama, maka itu adalah riba (Muhammad, 2012: 227). Keputusan Majelis Ulama Indonesia menyebutkan Bunga (Interest/fa'idah) adalah tambahan yang dikenakan dalam transaksi pinjaman uang (al-qardh) yang diperhitungkan dari pokok pinjaman tanpa mempertimbangkan pemanfaatan/ hasil pokok tersebut, berdasarkan tempo waktu, diperhitungkan secara pasti di muka dan pada umumnya berdasarkan persentase (Muhammad, 2012: 156).

\section{Konsep Kesejahteraan dalam Islam}

Kesejahteraan dalam perspektif ekonomi Islam adalah terpenuhinya kebutuhan materi dan non materi, dunia dan akhirat berdasarkan kesadaran pribadi dan masyarakat untuk patuh dan taat (sadar) terhadap hukum yang dikehendaki Allah swt melalui petunjuk-Nya dalam al-Qur'an, melalui keteladanan Rasulullah saw dan ijtihat para ulama (Agung, 2014: 40). Indikator kesejahteraan dalam AlQur'an yaitu menyembah Tuhan (pemilik) Ka'bah, menghilangkan lapar dan menghilangkan rasa takut. Indikator pertama ialah bentuk Penyembahan pada Allah akan memberikan kebahagiaan batin yang tidak bisa terpenuhi hanya dengan terpenuhinya kebutuhan materil. Indikator kedua yaitu menghilangkan rasa lapar sama halnya memenuhi kebutuhan konsumsi manusia, yang harus dilakukan tanpa berlebih-lebihan. Dan indikator yang ketiga yaitu terciptanya rasa nyaman, aman, tentram dan damai di tengah kehidupan 
masyarakat salah satu ciri telah fiber/ perahu, pedagang ecaran, tercapainya kesejahteraan (Amirus, pegawai swasta, pegawai 2015: 390-391).

Gambaran Umum Lokasi Penelitian

Kelurahan Barrang Caddi merupakan salah satu kelurahan yang berada di Kecamatan Kepulauan Sangkarrang yang terdiri dari lima pulau yang menjadi wilayah administrasinya yaitu Pulau LumuLumu, Pulau Lanjukang, Pulau Langkai, Pulau Bone Tambu dan Pulau Barrang Caddi dengan total wilayah secara keseluruhan mencapai 21 ha. Kelurahan Barrang Caddi Kecamatan Kepulauan Sangkarrang Kota Makassar memiliki 5 RW dan 20 RT, dengan pusat pemerintahannya berada di Pulau Barrang Caddi. Jumlah penduduknya sebanyak 4.425 Jiwa. Dari data tersebut digolongkan berdasarkan jenis kelaminnya laki-laki berjumlah 2.113 jiwa dan perempuan berjumlah 2.312 jiwa, sedangkan penduduk yang digolongkan wajib KTP sebanyak 2.925 dan Jumlah KK 1.079. Mata pencaharian masyarakat Kelurahan Barrang Caddi Kecamatan Kepulauan Sangkarrang Kota Makassar 75\% berprofesi sebagai nelayan, sedangkan $25 \%$ terbagi pada bidang pembuat pemerintahan, trasnportasi dan pertukangan.

\section{Eksistensi Praktik Rentenir dalam} Kehidupan Masyarakat

Salah satu daerah dengan praktik rentenir yang masih eksis yaitu di Kelurahan Barrang Caddi, Kepulauan Sangkarrang Kota Makassar. Berdasarkan hasil penelitian praktik rentenir telah ada sejak 5 tahun yang lalu, tepatnya pada tahun 2013. Bisnis rentenir bermula dari sekumpulan ibu rumah tangga yang saling menceritakan kesulitan perekonomian keluarganya. Penghasilan suami yang tidak menentu setiap harinya, sedangkan kebutuhan hidup harus terpenuhi. Kesulitan perekonomian tersebut melahirkan ide untuk membantu suami dalam mencari nafkah dengan cara berjual kecilkecilan. Namun ide tersebut terkendala dengan tidak adanya modal (Ibu MN, 2018). Modal awal yang digunakan rentenir untuk mendirikan usahanya ialah sebesar Rp. 3.000.000,-.Rentenir menggunakan dana pribadi tanpa meminjam pada Bank maupun lembaga lainnya sebagai modalnya selama ini. 
Mekanisme utang piutang Nasabahnya akan terbiasa untuk rentenir yang berada di Kelurahan menyisihkan sebagian penghasilannya Barrang Caddi Kecamatan Kepulauan untuk membayar utang dan tidak Sangkarrang Kota Makassar merasa berat. Bukan hanya itu, sistem mempunyai cara yang sangat mudah cicilan setiap hari akan memberikan dan cepat tanpa adanya proses kemudahan komunikasi dan hubungan administrasi yang panjang. Hal itu berlaku bukan hanya pada pedagang eceran, namun pada semua masyarakat yang ingin menggunakan jasanya. Bagi masyarakat yang menginginkan pinjaman modal dari rentenir cukup mendatangi rumah rentenir lalu mengajukan jumlah pinjaman yang diinginkan. Tanpa adanya penahanan KTP, BPKB atau pun barang berharga lainnya sebagai jaminan, hal tersebut dikarenakan masyarakat masih memiliki rasa saling mempercayai satu sama lainnya. Setiap peminjaman akan diberikan bunga 20\% dari pokok (Ibu $\mathrm{MN}, 2018$ ).

Mekanisme pembayaran utang dilakukan dengan cara dicicil per hari selama 4 (empat) bulan, dan 1 (satu) bulan dalam kalender rentenir ialah 30 hari. Bunga yang diambil dari setiap peminjaman ialah sebesar $20 \%$. Sistem cicilan yang diberlakukan oleh rentenir dianggap lebih meringankan nasabahnya dalam pelunasan utangnya. yang baik antara rentenir dan pedagang eceran.

\section{Dampak Praktik Rentenir Terhadap}

\section{Kesejahteraan Pedagang Eceran}

Kesejahteraan dalam Islam harus memenuhi 2 (dua) indikator yaitu terpenuhinya kebutuhan material dan kebutuhan spiritual. Dalam penelitian ini, indikator terpenuhinya kebutuhan materil yaitu menghilangkan rasa lapar sama halnya memenuhi kebutuhan konsumsi manusia. Dan indikator terpenuhinya kebutuhan spirirtual yaitu penyembahan pada Allah dengan tidak terlibat dalam kegiatan riba dan ketenangan dalam menjalani hidup. Indikator yang pertama yaitu terpenuhinya kebutuhan material. Kebutuhan material ialah kebutuhan yang nampak oleh mata, dapat dirasakan oleh panca indera dan dapat digunakan manfaatnya. Kebutuhan material dapat terpenuhi dengan mengandalkan penghasilan. Penghasilan masyarakat di Kelurahan 
Barrang Caddi Kecamatan Kepulauan Sangkarrang Kota Makassar bervariasi sesuai dengan profesi yang ditekuni. Mayoritas masyarakat yang berprofesi sebagai nelayan memiliki penghasilan yang tidak menentu tergantung pada kondisi cuaca. Penghasilan nelayan saat cuaca sedang bagus berkisar antara Rp. 3.000.000 sampai Rp. 6.000.000, sedangkan ketika cuaca buruk penghasilan nelayan sangat menururn berkisar antara Rp. 1.000.000 sampai Rp. 1.500 .000 hal itu dikarenakan nelayan lebih sering tidak melaut (Bapak TB, 2018).

Pinjaman modal dari rentenir memberikan peluang bagi nelayan untuk membuka usaha baru yang memiliki penghasilan yang lebih bisa diandalkan untuk memenuhi kebutuhan hidupnya. Membaga usaha berdagang barang-barang eceran menjadi solusi yang efektif untuk meningkatkan penghasilan. Dengan berdagang dapat memperoleh penghasilan yang baik, yaitu berkisar antara Rp. 3.000.000 sampai dengan Rp. 7.500.000 per bulan (Bapak B, 2018).

Peningkatan penghasilan pedagang eceran tentunya berdampak pada mudahnya memenuhi kebutuhan materail keluarganya. Kebutuhankebutuhan dasar seperti sandang, pangan dan papan lebih mudah terpenuhi. Tanpa harus menunggu penghasilan dari melaut. Sehingga penghasilan dari hasil melaut dapat disimpan dan digunakan untuk memenuhi kebutuhan yang lainnya (Ibu HR, 2018). Di sisi lain, tak dapat dipungkiri bahwasanya penghasilan yang diperoleh habis terbagi untuk memenuhi kebutuhan hidup dan membayar cicilan, bahkan ketika ada kebutuhan yang mendesak, modal yang telah disisihkan untuk usahapun digunakan. Keterbatasan akan sumber modal tersebut mengakibatkan pedagang eceran terus menggantungkan usahanya terhadap asupan modal dari rentenir.

Adapun indikator kedua ialah terpenuhinya kebutuhan spiritual yaitu ketenangan dalam menjalani hidup. Utang kepada rentenir memberikan beban pikiran tambahan kepada para pedagang eceran. Utang yang terus menerus berlanjut membuat pedagang eceran semakin sulit terlepas dari jeratan hutang yang tentunya akan menambah beban hidup pedagang eceran. Selain harus memenuhi 
kebutuhan sehari-hari, pedagang eceran pun harus membayar cicilan hutang setiap harinya. Dimana beban utang bukan hanya berlaku di dunia melainkan juga akan berlanjut di kelak bila tidak mampu dilunasi. Oleh karena itu, ketenangan hidup yang terbebas utang belum dapat dirasakan oleh pedagang eceran.

Indikator kedua dari kebutuhan spiritual ialah tidak terlibat dalam praktik riba. Seluruh pedagang eceran yang menjadi informan beragama Islam dan pada umumnya paham akan pelarangan riba meskipun memiliki pendapat yang berbeda-beda. Namun kondisi yang mendesak membuat mereka menggunakan jasa rentenir dan terlibat dalam praktik riba. Kebutuhan akan modal dalam menjalankan usahanya yang harus terpenuhi sebagai upaya untuk memenuhi kebutuhkan hidup tidak dibarengi dengan keberadaan lembaga keuangan formal di Kelurahan Barrang Caddi Kecamatan Kepulauan Sangkarrang Kota Makassar. Sehingga dari kedua indikator terpenuhinya kebutuhan spiritual, kedua-duanya tidak ada yang terpenuhi. Dengan demikian, adanya praktik rentenir di Kelurahan Barrang
Caddi Kecamatan Kepulauan Sangkarrang Kota Makassar tidak mampu mensehjahterakan perekonomian pedagang eceran.

\section{Dampak Praktik Rentenir Terhadap} Kesejahteraan Pedagang Eceran ditinjau Menurut Prinsip Ekonomi Islam

Praktik rentenir ditengah masyarakat Kelurahan Barrang Caddi Kecamatan Kepulauan Sangkarrang Kota Makassar, memberikan manfaat bagi kehidupan perekonomian pedagang eceran. Bertindak sebagai lembaga keuangan non formal yang memenuhi kebutuhan akan modal berdampak pada peningkatan penghasilan pedagang eceran, meskipun secara keseluruhan kesejahteraan pedagang eceran tak dapat tercapai. Selain itu eksistensi rentenir dianggap telah menyalahi prinsip-prinsip ekonomi Islam yaitu prinsip keadilan, prinsip ta'awun dan prinsip maslahat.

\section{Prinsip Keadilan}

Praktik rentenir di Kelurahan Barrang Caddi Kecamatan Kepulauan Sangkarrang Kota Makassar telah menyalahi prinsip keadilan, dimana keadilan ialah bentuk kondisi 
kebenaran ideal secara moral akan meringankan masyarakat yang

sesuatu hal, baik itu menyangkut benda atau pun orang (Afifah, 2017: 3). Dengan menggunakan uang sebagai komoditas utama dengan adanya tambahan bunga sebagai jumlah keuntungan. Jelas menyalahi hakikat kebenaran dari uang yang merupakan alat tukar. Selain itu penentuan sepihak besaran bunga oleh rentenir secara tidak langsung telah memaksa pedagang eceran untuk menyetujuinyan tanpa adanya negosiasi sebelumnya. Selanjutnya praktik rentenir telah mengeksploitasi orang lain untuk mendapatkan keuntungan tanpa bersusah payah, menyalahi kebenaran akan kesamaan derajat diantara manusia. Hal tersebut berimbas pada kehidupan perekonomian pedagang eceran yang meskipun mengalami peningkatan penghasilan namun terus bergantung pada asupan modal dari rentenir.

\section{Prinsip Ta'awun (Tolong Menolong)}

Praktik retenir di Kelurahan Barrang Caddi Kecamatan Kepulauan Sangkarrang semata-mata untuk menuai keuntungan dan hanya berorientasi bisnis. Meskipun rentenir mangaku untuk membutuhkan. Namun pada dasarnya, niat utama dari rentenir hanyalah memperoleh keuntungan. Dengan menetapkan besaran bunga disetiap pinjamannya menandakan bahwa praktik rentenir hanya berorientasi memperoleh keuntungan. Bila rentenir tidak berorintasi memperoleh keuntungan, seharusnya ia dapat memberikan pinjaman tanpa menentukan bunga pada setiap transaksi.

Hal tersebut sangat bertolak belakang dengan prinsip ta'awun yang bermakna kerja sama, tolong menolong, saling menjamin, tidak berorientasi bisnis dan keuntungan semata (Havis, 2016: 37). Dalam praktiknya rentenir tidak melakukan kerja sama, melainkan hanya membuat salah satu pihak yang bekerja keras untuk mengembalikan pinjaman dana darinya. Rentenir tidak berorientasi menolong, melainkan menjadikan kesulitan orang lain sebagai ladang bisnis yang menguntungkan diri pribadi tidaklah dibenarkan dalam Islam.

Selanjutnya, pada praktiknya rentenir tidak menjamin atas untung dan rugi yang mungkin saja bisa terjadi 
pada usaha para pedagang eceran yang menjadi nasabahnya, melainkan rentenir telah menjamin keuntungan yang ia peroleh dari setiap transaksi utang piutang dengan menentukan besaran bunga sebagai keuntungan. Sehingga sangat jelas terlihat bahwa rentenir memiliki sisi egois sebagai agen kapitalis yang memikirkan keuntungannya sendiri.

Rentenir hanya berorientasi bisnis dan keuntungan semata, dimana pihak rentenir yang tidak pernah memberikan pinjaman secara cumacuma tanpa adanya tambahan bunga. Utang-piutang telah menjadi bisnis sampingan bagi rentenir dengan tanpa bersusah payah bekerja namun sudah dapat menghitung besaran keuntungan yang akan ia peroleh. Sehingga pedagang eceran yang membutuhkan modal harus menghadapi permasalahan baru yaitu terjerat oleh utang.

\section{Prinsip Maslahat}

Pada hakikatnya maslahat yang dikatakan oleh Mursal (2015: 80) ialah segala bentuk kebaikan dan manfaat yang berdimensi integral duniawi dan ukhrawi, material dan spritual, serta individual dan sosial. Aktivitas ekonomi dipandang memenuhi maslahat jika memenuhi dua unsur, yakni ketaatan (halal) dan bermanfaat serta membawa kebaikan (thayyib) bagi semua aspek secara integral. Berdasarkan dua unsur tersebut dapat dilihat bahwasanya bisnis rentenir yang menggunakan mekanisme riba dalam praktiknya telah menyalahi unsur halal maupun thayyib.

Menyalahi unsur halal, Islam dengan tegas mengharamkan riba. Dan harus dipahami bahwasanya kriteria berlipat-ganda bukanlah merupakan syarat dari terjadinya riba (jikalau bunga berlipat ganda maka riba, tetapi jikalau kecil bukan riba), tetapi ini merupakan sifat umum dari praktek pembungaan uang pada saat itu (Muhammad, 2007: 216). Meskipun bunga yang diambil rentenir di Kelurahan Barrang Caddi Kecamatan Kepulauan Sangkarrang Kota Makassar relatif kecil yaitu 20\%, namun tetap dikatakan sebagai riba yang diharamkan dalam Islam yang tentunya berdosa bagi yang melakukannya. Bahkan dosa teringan bagi pelaku riba ialah sama dengan menzinahi ibu kandung. Menyalahi unsur thayyib, hal ini dapat dilihat bahwasanya bisnis rentenir tidak memberikan kebaikan 
bagi masyarakat, justru menimbulkan modal dan tidak adanya lembaga kemudharatan duniawi maupun keuangan formal, serta mekanisme ukhrawi. Kemudharatan duniawi dapat utang piutang yang dilakukan dengan dilihat bahwa kesejahteraan pedagang proses yang mudah tanpa prosedur dan eceran tidak meningkatkan namun persyaratan yang rumit serta sebaliknya pedagang eceran semakin pembayaran utang menggunakan bergantung pada rentenir dan tidak bisa sistem cicil per hari. Rentenir mandiri menjalankan bisnisnya. memberikan dampak negatif pada Kemudharatan ukhrawi yang kesejahteraan pedagang eceran. ditimbulkan ialah rentenir telah Kesejahteraan tercapai bila membawa pedagang eceran ke dalam terpenuhinya kebutuhan material dan praktik riba yang diharamkan dalam spiritual, pinjaman modal dari rentenir Islam. Dengan ikut dalam praktik riba, hanya mampu memenuhi kebutuhan maka pedagang eceran telah melakukan materialnya, namun tidak pada perbuatan dosa yang akan mendapatkan kebutuhan spiritual. Praktik riba yang balasan di akhirat kelak. dilakukan rentenir telah menyalahi

\section{KESIMPULAN}

Eksistensi rentenir telah ada sejak prinsip ekonomi Islam yaitu prinsip keadilan, prinsip ta'awun dan prinsip tahun 2013 dikarenakan kebutuhan muslahat.

\section{DAFTAR PUSTAKA}

Aravik, Havis. 2016. “Asuransi dalam Perspektif Islam”. Nurani. Vol. 16, No.2

Arief, Moh. Zainol dan Sutrisni. 2013. "Praktek Rentenir Penghambat Terwujudnya Sistem Hukum Perbankan Syariah Di Kabupaten Sumenep". Jurnal Performance Bisnis \& Akutansi, Vol. 3, No.2: 63-82.

Deliarnov. 2006. Ekonomi Politik. Jakarta: Erlangga.

Departemen Pendidikan dan Kebudayaan. 1995. Kamus Besar Bahasa Indonesia. Ed. ke-2; Cet. Ke-4; Jakarta: Balai Pustaka.

Fitria, Tira Nur. 2016. "Kontribusi Ekonomi Islam dalam Pengembangan Ekonomi Nasional”. Jurnal Ilmiah Ekonomi Islam. Vol. 2, No. 3: 29-40.

Imarah, Muhammad. 1999. Islam dan Keamanan Sosial. Jakarta: Gema Insani.

Jirhanuddin, Ahmad Dakhoir, dan Sulistyaningsih. 2016. "Manajenem Dana Iuran Rukun Kematian di Putun Kota Palangka Raya". Jurnal Al-Qardh. Vol. 2, No. 5: $127-140$ 
Johan Nasution, Bahder. 2014. "Kajian Filosofi Tentang Konsep Keadilan dari Pemikiran Klasik sampai Pemikiran Modern”. Yustisia. Vol. 3, No. 2: 118130.

Khaeriyah, Hamzah Hasan. 2013. Ekonomi Islam. Makassar: Alauddin University Press.

Mursal. 2015. "Implementasi Prinsip-prinsip Ekonomi Syariah: Alternatif Mewujudkan Kesejahteraan Berkeadilan". Jurnal Perspektif Ekonomi Darussalam. Vol. 1, No. 1: 75-84.

Nurdin. 2011. "Konsep Keadilan dan Kedaulatan dalam Perspektif Islam dan Barat". Media Syariah. Vol. 13, No. 1: 121-130.

Panjaitan, Frans E dan Nofrion dan Ratna Wilis. 2018. "Praktik Pelepasan Uang/ Rentenir Di Nagari Lubuk Basung Kabupaten Agam Sumatera Barat". Jurnal Buana, Vol. 2, No. 1: 397-409.

PIU Kota Makassar. 2015. ICM Kelurahan Barrang Caddi Tahun 2015, http://ccdp-ifad.org/mis2/alam/rendes/42.pdf (08 Agustus 2018).

Purwana, Agung Eko. 2014. Kesejahteraan dalam Perspektif Ekonomi Islam. Islamica. Vol. 11, No.1: 21-42.

Rangkuti, Afifa. 2017. Konsep Keadilan dalam Perspektif Islam”. Jurnal Pendidikan Islam. Vol. 6, No.1: 1-21.

Saeed, Abdullah. 2004. Menyoal Bank Syariah. Jakarta: Paramadina.

Shihab, M. Quraish. 2007. Tafsir Al-Misbah. Jakarta: Lentera Hati.

Sodiq, Amirus. 2015. “Konsep Kesejahteraan dalam Islam”. Equilibrium. Vol. 3, No.2:381-405.

Sukidin. 2009. Sosiologi Ekonomi. Yogyakarta: Center For Society Studies.

Surahman, Maman dan Panji Adam. 2017. "Penerapan Prinsip Syari'ah pada Akad Rahn di Lembaga Pegadaian Syariah”. Jurnal law and Justice. Vol. 2, No. 2: 135-146.

Yanti, Illi dan Rafidah. 2009. "Ekonomi Islam dalam Sistem Ekonomi Indonesia (Studi Tentang Prinsip-Prinsip Ekonomi Islam dan Implementasinya terhadap Ekonomi Nasional)”. Kontekstualita. Vol 25, no. 1: 13-30.

Yusuf, Muhammad Yasir. 2012. "Dinamika Fatwa Bunga Bank di Indonesia: Kajian terhadap fatwa MUI, Muhammadiyah dan Nahdlatul Ulama". Media Syari'ah. Vol. 17, No. 2: 151-159. 